\title{
Serological and Molecular Investigations of Babesia Microti in Dogs from Southern Italy
}

\author{
Elisabetta Giudice ${ }^{1}$, Simona Di Pietro ${ }^{2}$, Valeria Blanda ${ }^{3}$, Valentina Rita Francesca Bosco ${ }^{2}$, Rossella Lelli ${ }^{3}$ and Alessandra Torina ${ }^{2,3}$ \\ ${ }^{1}$ Dipartimento di Scienze Biologiche e Ambientali, University of Messina, Via F. Stagno D'Alcontres n. 31, 98166 Messina, Italy \\ ${ }^{2}$ Department of Veterinary Sciences, University of Messina, Polo Universitario Annunziata, 98168 Messina, Italy \\ 3/stituto Zooprofilattico Sperimentale della Sicilia “A. Mirri” Via Gino Marinuzzi, 3 - 90129 Palermo, Italy
}

*Corresponding author: Simona Di Pietro, Department of Veterinary Sciences, University of Messina, Polo Universitario Annunziata, 98168 Messina, Italy, Tel: +390903503509; E-mail: dipietros@unime.it

Rec date: Jul 21, 2015; Acc date: Oct 14, 2015; Pub date: Oct 16, 2015

Copyright: $\odot 2015$ Giudice E, et al. This is an open-access article distributed under the terms of the Creative Commons Attribution License, which permits unrestricted use, distribution, and reproduction in any medium, provided the original author and source are credited.

\begin{abstract}
Piroplasmosis is now considered emerging tick-borne zoonosis worldwide and domestic animals have been proposed as potential reservoirs for some piroplasm infections. The aim of this research was to identify the frequency of Babesia microti infection in untravelled dogs from Southern Italy (Sicily). Blood samples from 89 dogs were examined for the presence of Babesia microti antibodies and DNA. The dogs were infested with ticks. Among the examined dogs only one $(1.16 \%)$ had $B$. microti antibodies, associated to $B$. canis, $A$. phagocytophilum and $R$. conorii infections. In the PCR assay, the dog was also found positive for $B$. microti and $R$. conorii DNA, and negative for other microorganisms. The infected dog showed a non-specific flu-like syndrome, with depression, disorexia, hyperthermia $\left(39.6^{\circ} \mathrm{C}\right)$, light dehydration, moderate lymphadenopathy and heavy tick infestation $(>20)$. No significant changes were present in the cell blood count. To the best of our knowledge, this is the first report of serological and molecular identification of B. microti piroplasm in a dog from Southern Italy. Because specific antibodies and DNA were detected in an untraveled dog, babesiosis is probably due to an autochthonous tick infection. However, this study indicates that Babesia microti is not widely distributed in dog populations in Sicily, as demonstrated by low prevalence of infection. So, in Sicily the dog would not appear to represent a reservoir of infection, but rather an accidental host.
\end{abstract}

Keywords: Babesia microt; Dog; PCR; Southern Italy

\section{Abbreviations:}

CBC: cell blood count; C.R.A.Ba.R.T: National Reference Centre for Anaplasma, Babesia, Rickettsia and Theileria; ELISA: enzyme-linked immunosorbent assay; IFAT: immunofluorescent antibody test; IZS: Istituto Zooprofilattico Sperimentale; K3 EDTA: tri-potassium ethylenediaminetetraacetic acid; PCR: polymerase chain reaction; RBC: red blood cell; TBD: tick borne disease

\section{Introduction}

Babesiosis, otherwise known as piroplasmosis, is a blood-borne infection of particular concern due to the severity of the clinical signs, which infect a variety of domestic and wild animals, and humans $[1,2]$. Canine babesiosis is a tick borne disease caused by an obligate intraerythrocytic parasite, genus Babesia (Apicomplexa: Piroplasmida) [3]. After host invasion Babesia spp. sporozoites parasitize RBCs, evolve into ring-shaped trophozoites and then replicate forming merozoites that move freely in the host cell cytoplasm [4]. Merozoites may further divide forming 4-8 or more parasites in the same RBC and eventually destroying the cell and become free in the blood to invade new cells [2]. In most European countries, B. canis is recognized as the principal etiological agent in canine piroplasmosis, but molecular and phylogenetic analyses suggest the presence of other species of piroplasms [3].
Traditionally, it was assumed that the only Babesia species causing disease in dogs were Babesia canis and Babesia gibsoni [5], but recently published reports demonstrate that different piroplasm species can parasitize dogs [2,6-9].

B. rossi, B. canis and B. vogeli, previously considered as subspecies of $B$. canis, are identical morphologically but demonstrate tremendous variations in geographic distribution, vector specificity, genetic characteristics, and clinical signs which they induce in dogs. These parasites are currently considered as separate species [2].

In Italy, B. canis is mainly described in the North and less frequently in Central regions, while $B$. vogeli is predominantly found in Central and Southern Italy [10].

The development of molecular methods has demonstrated that more piroplasmid species infect dogs. These include the small piroplasms Babesia conradae [7,11], Babesia microti-like piroplasm [9], which is also referred to as Theileira annae [6,9] or "Spanish dog isolate" [8], and Theileria spp. [2,12].

Babesia microti is the most common cause of human babesios. It is endemic in North America and has recently emerged in Europe and East Asia. Infection usually causes asymptomatic to mild flu-like clinical manifestations including fever, sweat, chills and anemia. However, severe and sometimes fatal outcomes generally occur in immunocompromised or elderly individuals $[13,14]$.

A new pathogenic B. microti-like species from dogs was first described in a German dog infected during a trip to Northwestern region of Spain $[9,15]$. 
Citation: Giudice E, Pietro SD, Blanda V, Bosco VRF, Lelli R, et al. (2015) Serological and Molecular Investigations of Babesia Microti in Dogs from Southern Italy. J Veterinar Sci Technol 6: 261. doi:10.4172/2157-7579.1000261

Page 2 of 6

B. microti-like piroplasm had been molecularly sequenced from infected dogs with clinical babesiosis from Galicia northwestern Spain, [6] and in sick dogs from northern Portugal [16].

There are reports of infection in a few clinically healthy dogs: one from Tarragona, northeastern Spain [17], another one from Croatia [18] and an additional one from the US [8]. DNA of the B. microti or B. microti-like piroplasms has also been detected in several species: in foxes from Italy [19,20], Central and Northern Spain [21-23], Portugal [24], North America [15], and Croatia [25]; in cats from Portugal [26] and Italy [27,28]; in a donkey from Northern Spain [29]; in roe deers from Italy [30]; in feral raccoons from Japan [31]. Molecular analyses also detected the parasite DNA in Ixodes ricinus and Rhipicephalus sanguineus ticks from Italy [1,3], in I. ricinus and Ixodes hexagonus from Northern Spain [23] and in I. ricinus in Poland [32].

A potential role in the parasite transmission seems to be attributed to birds ticks. In fact, a recent research revealed positivity to $B$. microti infection in two larvae of bird-fed ticks [33].

The pathology that Babesia inflicts in the host varies considerably with the different species and sub-species involved, and also with the host's individual immune status, age, concurrent infections or illness and response to infection [34]. Haemolytic anemia and systemic inflammatory response syndrome leading to multiple-organ dysfunction syndrome account for most of the clinicopathological abnormalities observed in canine and feline babesiosis $[35,36]$. In general, Babesia species cause a haemolytic anemia which is multifactorial and is the predominant clinical manifestation inducing a number of immune responses that may have a devastating influence [37]. Haemolytic anemia can occur due to direct red blood cell lysis by replicating intracellular parasites which cause a combination of intravascular and extravascular haemolysis [2].

The most frequent clinical findings reported in dogs infected with $\mathrm{B}$. microti-like piroplasm are weakness, fever, lethargy, tachycardia and tachypnea [2]. Azotemia, hyperphosfatemia, hypoalbuminemia, hypercholesterolemia, proteinuria and high urine protein/creatinine ratios suggest a glomerular component to the disease [38].

In light of these findings and since that only few studies investigating the presence of this parasite in dogs of the Mediterranean area are available, the aim of this work was to verify the prevalence of B. microti in untraveled dogs from several areas of Sicily.

\section{Materials and Methods}

The study was conducted on 86 dogs from different areas of Sicily (Southern Italy), during the period May-October 2005. All the subjects differed for breed, gender, age and management (kennel, farm and family dog). Relatively to the origin, the dogs were divided as follows: 26 were from Caltanissetta $\left(37.49^{\circ} \mathrm{N}, 14.04^{\circ} \mathrm{E} ; 597 \mathrm{~m}\right.$. a.s.l. $), 7$ from Catania $\left(37.5^{\circ} \mathrm{N}, 15.09^{\circ} \mathrm{E} ; 19 \mathrm{~m}\right.$. a.s.l.) and 53 from Messina $\left(38.19^{\circ} \mathrm{N}\right.$, $15.55^{\circ}$ E; 59 m. a.s.l.) (Table 1 and Figure 1).

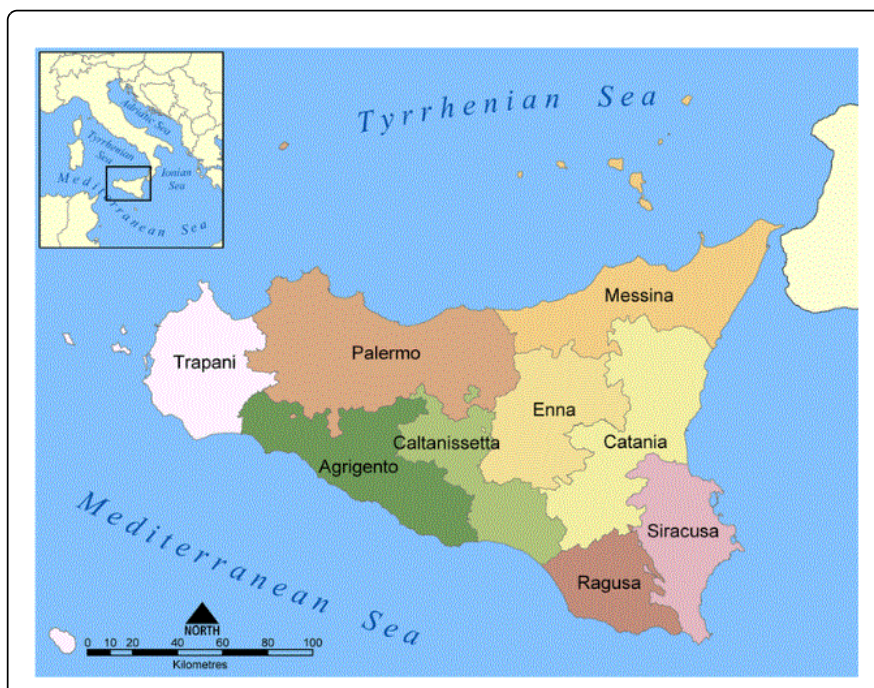

Figure 1: Provenience of dogs.

All the animals present at the moment of the inspection of the facilities (kennels, farms or veterinary clinics) were enrolled for the study. Animal shelters and pet owners consented to have their animals involved in this study.

\begin{tabular}{|c|c|c|c|c|c|c|}
\hline \multirow[t]{2}{*}{ Provenience } & \multirow[t]{2}{*}{ Facilities } & \multirow[t]{2}{*}{ Nr. } & \multirow[t]{2}{*}{ Breed } & \multirow{2}{*}{$\begin{array}{l}\text { Age } \\
\text { (years) }\end{array}$} & \multicolumn{2}{|c|}{ Gender } \\
\hline & & & & & Male & Female \\
\hline \multirow[t]{3}{*}{ Caltanissetta } & Kennel 1 & 14 & Mongrel & $3-5$ & 2 & 12 \\
\hline & Kennel 2 & 8 & Mongrel & $3-5$ & 2 & 6 \\
\hline & Owned dogs & $\begin{array}{l}2 \\
2\end{array}$ & $\begin{array}{l}\text { Corso dog } \\
\text { Mongrel }\end{array}$ & $>1$ & 2 & 2 \\
\hline Catania & Sheep Farm & 7 & Mongrel & $1-4$ & 3 & 4 \\
\hline \multirow[t]{2}{*}{ Messina } & Kennel 3 & $\begin{array}{l}16 \\
1 \\
1 \\
1\end{array}$ & $\begin{array}{l}\text { Mongrel } \\
\text { Pointer } \\
\text { English Setter } \\
\text { Syberian Husky }\end{array}$ & $4-10$ & 10 & 9 \\
\hline & Kennel 4 & $\begin{array}{l}7 \\
2\end{array}$ & $\begin{array}{l}\text { Mongrel } \\
\text { English Setter }\end{array}$ & $4-8$ & 6 & 6 \\
\hline
\end{tabular}




\begin{tabular}{|c|c|c|c|c|c|c|}
\hline & & $\begin{array}{l}1 \\
1 \\
1\end{array}$ & $\begin{array}{l}\text { Cirneco of Etna } \\
\text { German Sheperd } \\
\text { Shi tzu }\end{array}$ & & & \\
\hline & Veterinary Hospital & $\begin{array}{l}8 \\
2 \\
2 \\
2 \\
1 \\
1 \\
1 \\
2 \\
1 \\
1 \\
1\end{array}$ & $\begin{array}{l}\text { Mongrel } \\
\text { Labrador Retriever } \\
\text { German Sheperd } \\
\text { Italian Hound } \\
\text { Epagneul Breton } \\
\text { Rottweiler } \\
\text { Shit-tzu } \\
\text { German Hound } \\
\text { Dachsund } \\
\text { Syberian Husky } \\
\text { Samoeido }\end{array}$ & $4-10$ & 12 & 10 \\
\hline Total & & 86 & & $1-10$ & 37 & 49 \\
\hline
\end{tabular}

Table 1: Group of examined dogs.

All the subjects after a general physical examination and a measurement of rectal temperature were venipunctured from cephalic or saphenous vein and blood samples were collected. Immediately after collection, the blood was stored at refrigerating temperature into tubes containing K3 EDTA and into tubes containing separating gel pending analysis. On the blood samples, within $8 \mathrm{hr}$ from collection, a complete $\mathrm{CBC}$ was performed by means of an automated analyzer (Hemat 8 , Seac, Florence, Italy).

On individual sera, IFAT for the research of anti-B. microti antibody was performed.

On each wool blood samples, B. microti DNA was detected using a PCR.

Each sample was simultaneously checked for B. canis, Ehrlichia canis, Rickettsia conorii and Anaplasma phagocytophilum.

The serological and molecular investigations were performed by the C.R.A.Ba.R.T. of the IZS "A. Mirri” of Sicily.

\section{Serological and molecular assays}

IFAT kits for B. microti (Fuller Laboratories, Fullerton, CA, USA) were used following manufacturer's recommendations. An antibody titre of 1:64 or greater was considered positive for B. microti antigens.

\section{Molecular analysis}

DNA was extracted using the PureLink Genomic Mini kit (Applied Biosystem Corporation) and quantified by Nanodrop ND1000 Spectrophotometer (NanoDrop Technologies, Wilmington, DE).

Nucleic acids were analyzed by PCR to detect the presence of Babesia microti DNA. PCRs were assessed using GoTaq Polymerase (Promega), as previously reported [39].

The amplification of $18 \mathrm{~S}$ rRNA region of $B$. microti was carried out using the primers BAB1 (5'-CTTAGTATAAGCTTTTATACAGC-3') and BAB4 (5'-ATAGGTCAGAAACTTGAATGATACA-5'). The amplicon expected length was $238 \mathrm{bp}$ for Babesia microti.
PCRs were carried out in buffer $1 \times, 0.4 \mu \mathrm{M}$ of each primer, $1.5 \mathrm{mM}$ of $\mathrm{MgCl} 2,0.2 \mathrm{mM}$ of dNTPs, $1.25 \mathrm{U}$ of Taq Polymerase (Promega, GoTaq DNA Polymerase).

The thermal profile of PCR was: 4 minutes at $94^{\circ} \mathrm{C}$ for denaturation followed by 35 cycles with denaturation at $94^{\circ} \mathrm{C}$ for 1 minute, annealing at $55^{\circ} \mathrm{C}$ for 50 seconds, and extension at $7^{\circ} \mathrm{C}$ for 1 minute. The final extension step was 5 minutes at $72 \mathrm{C}$. In each reaction a positive control, consisting of pathogen DNA, and a negative control, in which DNA was replaced by water, were used. PCR products were visualized after electrophoretic migration on agarose gel containing ethidium bromide $10 \mu \mathrm{g} / \mathrm{ml}$. PCR products were purified by a PCR and gel purification kit (Promega Wizard SV Gel and PCR Clean-up System), cloned into a cloning vector (Invitrogen pCR2.1 TOPO TA cloning kit), quantified and sent for sequencing (Macrogen, Inc., Seoul, South Korea). Obtained sequences were aligned using Bioedit software (Tom Hall, Ibis Biosciences) and ClustalW 2.0.10 and analysed for nucleotide sequence identity by comparing them with reference strains.

\section{Results}

The general clinical examination of the recruited dogs showed that all were infested with ticks.

Among the examined dogs only one $(1,16 \%)$ had $B$. microti antibodies, associated to B. canis, $A$. phagocytophilum and $R$. conorii infections. In the PCR assay, the dog was also found positive for $B$. microti and R. conorii DNA, and negative for other microorganisms. B. microti isolate showed $100 \%$ homology with the GenBank closest sequence AY693840.1, the B. microti isolate Gray 18 S ribosomal RNA gene, described by Slemenda SB, Herwaldt BL. and Pieniazek NJ. in the USA in 2004 (unpublished data) and isolated from human.

Physical examination of the infected dog revealed: depression, disorexia, hyperthermia $\left(39.6^{\circ} \mathrm{C}\right)$, light dehydration, moderate lymphadenopathy and heavy tick infestation $(>20)$. The dog was a 2year-old female autochthon sheepdog lived in an organic sheep dairy farm located in Ramacca municipality (province of Catania; Oriental 
Page 4 of 6

Sicily; Southern Italy). The six other consanguineous dogs living in the farm was variously positive against TBDs but negative for the research of B. microti antibodies and DNA. In Table 2 is reported the haematological pattern of the infected dog.

\begin{tabular}{|c|c|c|}
\hline Parameter & Observed values & Reference values ${ }^{*}$ \\
\hline Red blood cells $\left(10^{6} / \mu \mathrm{L}\right)$ & 6.22 & $5.50-7.90$ \\
\hline White blood cells $\left(10^{3} / \mu \mathrm{L}\right)$ & 13.27 & $6.0-16.0$ \\
\hline Haemoglobin (g/dL) & 13.60 & $12-18$ \\
\hline Haematocrit (\%) & 40.10 & $37-55$ \\
\hline $\mathrm{MCV}(\mathrm{fL})$ & 64.50 & $60-76$ \\
\hline $\mathrm{MCH}(\mathrm{Pg})$ & 21.95 & $20-27$ \\
\hline $\mathrm{MCHC}(\mathrm{g} / \mathrm{dL})$ & 34 & $32.0-38.0$ \\
\hline $\operatorname{PLT}\left(10^{3} / \mu \mathrm{L}\right)$ & 380 & $240-400$ \\
\hline MPV (fL) & 9.55 & $4.9-7.0$ \\
\hline РСТ (\%) & 0.38 & $0.150-0.300$ \\
\hline RDW (\%) & 13.05 & $12-16$ \\
\hline
\end{tabular}

Table 2: Haematological parameters of the B. microti infected dog. ${ }^{*}$ Hemat 8 , Seac, Florence, Italy.

The Figure 2 shows the electrophoresis of PCR amplification product from the B. microti positive sample.

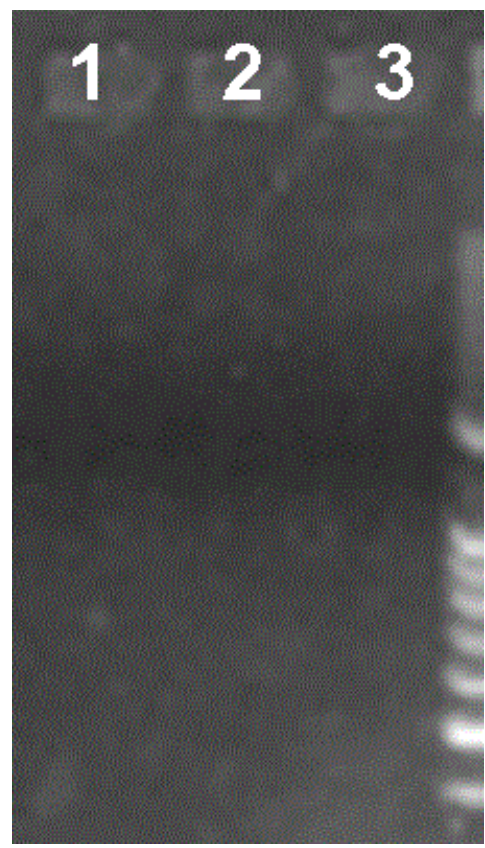

Figure 2: Ethidium bromide-stained $1.5 \%$ agarose gel electrophoresis of amplification products from a B. microti positive sample (lane 1), negative control (lane 2), positive control (lane 3); lane 4: 100-bp ladder. N.B. bp: base pair.

\section{Discussion}

To the best of our knowledge, this is the first report of serological and molecular identification of B. microti piroplasm in a dog from Southern Italy. Because specific antibodies and DNA were detected in an untraveled dog, babesiosis is probably due to an autochthonous tick infection.

Climatic conditions in Sicily make ectoparasitic infestations as endemic, especially in kennels. In Italy, dogs and cats living in public shelters may be at high risk of acquiring vector-borne pathogens, mainly because they are often untreated against ectoparasites, so representing an easy feeding source for them [40].

The positive animal was a shepherd dog with a high burn of tick infestation. The dog lived in an organic sheep dairy farm, in which a significant presence of ticks was detected. The type of farming has certainly favored the proliferation of parasites, since these farms not allowed the use of pharmacological treatments both on animals and environment. In addition, in this habitat there was a greater chance of being exposed to small rodents, considered to be the main reservoirs of the infection [41].

A recent study seems to confirm that not all the ticks are capable to improve the piroplasm diffusion. $R$. sanguineus is a well-known vector of piroplasms affecting farm animals and pets [1] and it is one of the most widespread ticks in Sicily.

The low prevalence recorded in the present study is in agreement with previous research conducted in Italy, in which were not found serological and molecular positivity to the parasite in dogs [42]. This finding is much different, however, from what has been observed in Germany, where $15 \%$ of the examined dog population showed seropositivity to $B$. microti [43]. Our results differs also from that observed in other animal species in Sicily, where the parasite DNA has been found in $30 \%$ of examined cats (6 out of 20) [27], and in $11 \%$ of foxes ( 1 of 9) [19], although the latter data have not been confirmed by subsequent studies, in which no foxes (0 of 13) were infected [44]. In Sicily, the dog, unlike the cat, would not appear to represent a reservoir of infection, but rather an accidental host.

In B. microti infection seems that seroconvertion appears prior to the onset of parasitemia, and since antibodies persist even after parasites are cleared, IFAT and ELISA often fail to distinguish an active from a resolved infection [4].

Moreover, with serological methods, a cross-reaction between different Babesia types is possible, as showed from other authors $[45,46]$. Our dog was also seropositive to B. canis, but no specific DNA was detected suggesting a possible cross reactivity with $B$. microti and other Babesia spp. [47].

In the present study, the definitive diagnosis of B. microti piroplasm infection was achieved only by PCR results. Sensitive molecular detection and species identification are important for the selection of the appropriate therapy and for prognosis, as well as for the screening of subclinical infections and of blood donors $[16,48]$.

The infected dog showed a specific clinical picture, without significant changes in the $\mathrm{CBC}$.

Although in humans a similar symptomatology is described $[49,50]$, the clinical findings may be reported generically to tick-borne diseases, also associated. Moreover, the clinical signs found in the present case could be attributed to the simultaneous presence of other pathogens, which infections could be favored by the rural housing conditions. In 
fact, the dog was also seropositive for $R$. conorii, A. phagocytophilum and $B$. canis, although DNA was found only for $R$. conorii than $B$. microti.

Even if the CBC of the infected dog did not show any relevant changes, anemia and moderate to severe thrombocytopenia are common findings among dogs infected with $B$. microti-like piroplasm $[16,51,52]$. The mechanisms related with severe hemolytic anemia may be more dependent on the host immune response than on the direct destruction of RBC by the piroplasm [53]. Mechanisms of local or systemic intravascular coagulopathy, immune-mediated destruction or splenic sequestration may be implicated in severe thrombocytopenias. On the other hand, the almost constant presence of macroplatelets in blood smears is associated with a bone marrow regenerative response to platelet consumption, as well as sequestration or destruction [53]. Camacho-García [6] describes that half the dogs with piroplasmosis due to B. microti-like piroplasm had normal leukocyte counts. Nevertheless, the values may range between leukopenia and leukocytosis, with the latter reaching extreme counts compatible with a leukemoid response in immune-mediated hemolytic anemia [52].

The risk of $B$. microti spreading infection to other European countries via dog travel or infected vector transport should increase the efforts to prevent the infection [16].

Since B. microti and B. microti-like were found in several European territories, the level of attention to these pathogens must remain high and further studies must be conduct with a larger sample size using diagnostic methods based on the DNA sequencing.

\section{Acknowledgements}

The authors declare that this research not received any funding.

\section{Conflict of interest}

The authors declare that no competing financial interests exist.

\section{Ethical statement}

All treatments, housing and animal care reported above were carried out in accordance with the standards recommended by the EU Directive 2010/63/EU for animal experiments.

\section{References}

1. Iori A, Gabrielli S, Calderini P, Moretti A, Pietrobelli M, et al. (2010) Tick reservoirs for piroplasms in central and northern Italy. Vet Parasitol 170: 291-296.

2. Solano-Gallego L, Baneth G (2011) Babesiosis in dogs and catsexpanding parasitological and clinical spectra. Vet Parasitol 181: 48-60.

3. Cassini R, Zanutto S, Frangipane di Regalbono A, Gabrielli S, Calderini P, et al. (2009) Canine piroplasmosis in Italy: epidemiological aspects in vertebrate and invertebrate hosts. Vet Parasitol 165: 30-35.

4. Borggraefe I, Yuan J, Telford SR, Menon S, Hunter R, et al. (2006) Babesia microti primarily invades mature erythrocytes in mice. Infect Immun 74: 3204-3212.

5. Cacciò SM, Antunovic B, Moretti A, Mangili V, Marinculic A, et al. (2002) Molecular characterisation of Babesia canis canis and Babesia canis vogeli from naturally infected European dogs. Vet Parasitol 106: 285-292.

6. García AT (2006) Piroplasma infection in dogs in northern Spain. Vet Parasitol 138: 97-102.
7. Kjemtrup AM, Conrad PA (2006) A review of the small canine piroplasms from California: Babesia conradae in the literature. Vet Parasitol 138: 112-117.

8. Yeagley TJ, Reichard MV, Hempstead JE, Allen KE, Parsons LM, et al. (2009) Detection of Babesia gibsoni and the canine small Babesia 'Spanish isolate' in blood samples obtained from dogs confiscated from dogfighting operations. J Am Vet Med Assoc 235: 535-539.

9. Zahler M, Rinder H, Schein E, Gothe R (2000) Detection of a new pathogenic Babesia microti-like species in dogs. Vet Parasitol 89: 241-248.

10. Solano-GallegoL, Trotta M, Carli E, Carcy B, Caldin M (2008) Babesia canis canis and Babesia canis vogeli clinicopathological ?ndings and DNA detection by means of PCR-RFLP in blood from Italian dogs suspected of tick-borne disease. Vet Parasitol 157: 211-221.

11. Kjemtrup AM, Wainwright K, Miller M, Penzhorn BL, Carreno RA (2006) Babesia conradae, sp. Nov., a small canine Babesia identified in California. Vet Parasitol 138: 103-111.

12. Matjila PT, Leisewitz AL, Oosthuizen MC, Jongejan F, Penzhorn BL (2008) Detection of a Theileria species in dogs in South Africa. Vet Parasitol 157: 34-40.

13. Masatani T, Ooka H, Terkawi MA, Cao S, Luo Y, et al. (2013) Identification, cloning and characterization of BmP41, a common antigenic protein of Babesia microti. J Vet Med Sci 75: 967-970.

14. Poisnel E, Ebbo M, Berda-Haddad Y, Faucher B, Bernit E, et al. (2013) Babesia microti: an unusual travel-related disease. BMC Infect Dis 13: 99.

15. Birkenheuer AJ, Horney B, Bailey M, Scott M, Sherbert B, et al. (2010) Babesia microti-like infections are prevalent in North American foxes. Vet Parasitol 172: 179-182.

16. Simões PB, Cardoso L, Araújo M, Yisaschar-Mekuzas Y, Baneth G (2011) Babesiosis due to the canine Babesia microti-like small piroplasm in dogs-first report from Portugal and possible vertical transmission. Parasit Vectors 4: 50 .

17. Tabar MD, Francino O, Altet L, Sánchez A, Ferrer L, et al. (2009) PCR survey of vectorborne pathogens in dogs living in and around Barcelona, an area endemic for leishmaniasis. Vet Rec 164: 112-116.

18. Beck R, Vojta L, Mrljak V, MarinculiÄ $\ddagger$ A, Beck A, et al. (2009) Diversity of Babesia and Theileria species in symptomatic and asymptomatic dogs in Croatia. Int J Parasitol 39: 843-848.

19. Torina A, Vicari D, Lo Valvo M, Agnone A, Reale F, et al. (2007) Research on Babesia parasites in Sicilian wild foxes. Parassitologia 49: 108.

20. Zanet S, Trisciuoglio A, Bottero E, de Mera IG, Gortazar C, et al. (2014) Piroplasmosis in wildlife: Babesia and Theileria affecting free-ranging ungulates and carnivores in the Italian Alps. Parasit Vectors 7: 70.

21. Criado-Fornelio A, Martinez-Marcos A, Buling-Saraña A, BarbaCarretero JC (2003a) Molecular studies on Babesia, Theileria and Hepatozoon in southern Europe. Part I. Epizootiological aspects. Vet Parasitol 113: 189-201.

22. Criado-Fornelio A1, Rey-Valeiron C, Buling A, Barba-Carretero JC, Jefferies R, et al. (2007) New advances in molecular epizootiology of canine hematic protozoa from Venezuela, Thailand and Spain. Vet Parasitol 144: 261-269.

23. Lledó L, Giménez-Pardo C, Domínguez-Peñafiel G, Sousa R, Gegúndez MI, et al. (2010) Molecular detection of hemoprotozoa and Rickettsia species in arthropods collected from wild animals in the Burgos Province, Spain. Vector Borne Zoonotic Dis 10: 735-738.

24. Cardoso L, Cortes HC, Reis A, Rodrigues P, Simões M, et al. (2013) Prevalence of Babesia microti-like infection in red foxes (Vulpes vulpes) from Portugal. Vet Parasitol 196: 90-95.

25. Dezdek D, Vojta L, CurkoviÄ $\ddagger$ S, Lipej Z, MihaljeviÄ $\ddagger$ Z, et al. (2010) Molecular detection of Theileria annae and Hepatozoon canis in foxes (Vulpes vulpes) in Croatia. Vet Parasitol 172: 333-336.

26. Criado-Fornelio A, Martinez-Marcos A, Buling-Saraña A, BarbaCarretero JC (2003b) Presence of Mycoplasma haemofelis, Mycoplasma haemominutum and piroplasmids in cats from southern Europe: a molecular study. Vet Microbiol 93: 307-317. 
Citation: Giudice E, Pietro SD, Blanda V, Bosco VRF, Lelli R, et al. (2015) Serological and Molecular Investigations of Babesia Microti in Dogs from Southern Italy. J Veterinar Sci Technol 6: 261. doi:10.4172/2157-7579.1000261

Page 6 of 6

27. Pennisi MG, Alongi A, Agnone A, Vitale F, Reale S, et al. (2007) Cats as reservoir of Babesia microti. Parassitologia 49: 100.

28. Spada E, Proverbio D1, Galluzzo P2, Perego R1, Bagnagatti De Giorgi G1, et al. (2014) Frequency of piroplasms Babesia microti and Cytauxzoon felis in stray cats from northern Italy. Biomed Res Int 2014: 943754

29. Gimenez C, Casado N, Criado-Fornelio A, de Miguel FA, DominguezPeñafiel G (2009) A molecular survey of Piroplasmida and Hepatozoon isolated from domestic and wild animals in Burgos (northern Spain). Vet Parasitol 162: 147-150.

30. Tampieri MP, Galuppi R, Bonoli C, Cancrini G, Moretti A, et al. (2008) Wild ungulates as Babesia hosts in northern and central Italy. Vector Borne Zoonotic Dis 8: 667-674.

31. Kawabuchi T, Tsuji M, Sado A, Matoba Y, Asakawa M, et al. (2005) Babesia microti-like parasites detected in feral raccoons (Procyon lotor) captured in Hokkaido, Japan. J Vet Med Sci 67: 825-827.

32. Sytykiewicz H, Karbowiak G, Hapunik J, Szpechcinski A, SuperganMarwicz M, et al. (2012) Molecular evidence of Anaplasma phagocytophilum and Babesia microti co-infections in Ixodes ricinus ticks in central-eastern region of Poland. Ann Agric Environ Med 19: 45-49.

33. Hildebrandt A, Franke J, Meier F, Sachse S, Dorn W, et al. (2010) The potential role of migratory birds in transmission cycles of Babesia spp., Anaplasma phagocytophilum, and Rickettsia spp. Ticks Tick Borne Dis 1: 105-107.

34. Irwin PJ (2009) Canine babesiosis: from molecular taxonomy to control Parasit Vectors 2 Suppl 1: S4.

35. Taboada J, Lobetti R (2006) Babesiosis. In: Greene, C.E. (Ed.), Infectious Diseases of the Dog and Cat. Saunders Elsevier, Philadelphia 722.

36. Matijatko V, Kis I, Torti M, Brkljacic M, Baric Rafaj R, et al. (2010) Systemic inflammatory response syndrome and multiple organ dysfunction syndrome in canine babesiosis. Veterinarski Arhiv 80: 611-626.

37. Ayoob AL, Hackner SG, Prittie J (2010) Clinical management of canine babesiosis. J Vet Emerg Crit Care (San Antonio) 20: 77-89.

38. Camacho AT, Guitian EJ, Pallas E, Gestal JJ, Olmeda AS, et al. (2004) Azotemia and mortality among Babesia microti-like infected dogs. J Vet Intern Med 18: 141-146.

39. Persing DH, Mathiesen D, Marshall WF, Telford SR, Spielman A, et al. (1992) Detection of Babesia microti by polymerase chain reaction. J Clin Microbiol 30: 2097-2103.

40. Otranto D, Dantas-Torres F (2010) Canine and feline vector-borne diseases in Italy: current situation and perspectives. Parasit Vectors 3: 2.
41. Kjemtrup AM, Conrad PA (2000) Human babesiosis: an emerging tickborne disease. Int J Parasitol 30: 1323-1337.

42. Pietrobelli M, Cancrini G, Moretti A, Tampieri MP (2007) Animal babesiosis: an emerging zoonosis also in Italy? Parassitologia 49 Suppl 1: 33-38.

43. Metz W (1999) Local and imported tick-borne infections in dogs in Germany Inauguraldissertation . School of Veterinary Medicine, Hannover, Germany, pp: 149

44. Torina A, Blanda V, Antoci F, Scimeca S, D'Agostino R, et al. (2013) A Molecular survey of Anaplasma spp., Rickettsia spp., Ehrlichia canis and Babesia microti in foxes and fleas from Sicily. Transbound Emerg Dis 60 Suppl 2: 125-130.

45. Ooka H, Terkawi MA, Goo YK, Luo Y, Li Y, et al. (2011) Babesia microti: molecular and antigenic characterizations of a novel $94-\mathrm{kDa}$ protein (BmP94). Exp Parasitol 127: 287-293.

46. Yamane I, Gardener JA, Ryan CP, Levy M, Urrico J, et al. (1994). Serosurvey of Babesia canis, Babesia gibsoni, and Erlichia canis in pound dogs in California, USA. Prev Vet Med 18: 293-304.

47. Sikorski LE, Birkenheuer AJ, Holowaychuk MK, McCleary-Wheeler AL, Davis JM, et al. (2010) Babesiosis caused by a large Babesia species in 7 immunocompromised dogs. J Vet Intern Med 24: 127-131.

48. Trotta M, Carli E, Novari G, Furlanello T, Solano-Gallego L (2009) Clinicopathological findings, molecular detection and characterization of Babesia gibsoni infection in a sick dog from Italy. Vet Parasitol 165: 318-322.

49. Krause PJ, Telford SR, Pollack RJ, Ryan R, Brassard P, et al. (1992) Babesiosis: an underdiagnosed disease of children. Pediatrics 89: 1045-1048.

50. Krause PJ, Telford SR, Spielman A, Sikand V, Ryan R, et al. (1996) Concurrent Lyme disease and babesiosis. Evidence for increased severity and duration of illness. JAMA 275: 1657-1660.

51. Camacho AT, Guitian FJ, Pallas E, Gestal JJ, Olmeda S, et al. (2005) Serum protein response and renal failure in canine Babesia annae infection. Vet Res 36: 713-722.

52. Guitián FJ, Camacho AT, Telford SR 3rd (2003) Case-control study of canine infection by a newly recognised Babesia microti-like piroplasm. Prev Vet Med 61: 137-145.

53. Boozer AL, Macintire DK (2003) Canine babesiosis. Vet Clin North Am Small Anim Pract 33: 885-904. 